\title{
Effects of forage provision to young calves on rumen fermentation and development of the gastrointestinal tract
}

\author{
L. Castells, ${ }^{*}$ A. Bach, ${ }^{*} \dagger$ A. Aris, ${ }^{*}$ and M. Terré ${ }^{* 1}$ \\ *Department of Ruminant Production, Institut de Recerca i Tecnologia Agroalimentàries (IRTA), 08140 Caldes de Montbui, Spain \\ †Institució Catalana de Recerca i Estudis Avançats (ICREA), 08010 Barcelona, Spain
}

\begin{abstract}
Fifteen Holstein male calves were randomly assigned to 1 of 3 dietary treatments according to age and body weight (BW) to determine the effects of feeding different forages sources on rumen fermentation and gastrointestinal tract (GIT) development. Treatments consisted of a starter (20\% crude protein, $21 \%$ neutral detergent fiber) fed alone (CON) or supplemented with alfalfa $(\mathrm{AH})$ or with oat hay $(\mathrm{OH})$. All calves received $2 \mathrm{~L}$ of milk replacer (MR) at $12.5 \%$ dry matter twice daily until $49 \mathrm{~d}$ of age. Calves received $2 \mathrm{~L}$ of the same MR from 50 to $56 \mathrm{~d}$ of age and were weaned at $57 \mathrm{~d}$ of age. Individual starter, forage, and MR intakes were recorded daily and BW was recorded weekly. A rumen sample was taken weekly to determine rumen $\mathrm{pH}$ and volatile fatty acid concentrations. Three weeks after weaning, animals were harvested and each anatomical part of the GIT was separated and weighed with and without contents. Rumen $\mathrm{pH}$ was lower in $\mathrm{CON}$ than in $\mathrm{OH}$ and $\mathrm{AH}$ calves. Furthermore, acetate proportion in the rumen liquid tended to be greater in $\mathrm{AH}$ than in $\mathrm{CON}$ and $\mathrm{OH}$ treatments. Total GIT weight, expressed as a percentage of $\mathrm{BW}$, tended to be greater in $\mathrm{AH}$ compared with the other 2 treatments. Rumen tissue tended to weigh more in $\mathrm{CON}$ than in $\mathrm{OH}$ animals. Animals with access to forage tended to have a greater expression of monocarboxylate transporter 1 than $\mathrm{CON}$ calves. In conclusion, calves supplemented with oat hay have a better rumen environment than calves offered no forage and do not have an increased gut fill.
\end{abstract}

Key words: calf, gene expression, gut, intake

\section{INTRODUCTION}

During recent years, several studies have attempted to define the most appropriate solid diet for calves during the preweaning period (Bach et al., 2007; Khan et al., 2011; Castells et al., 2012). However, there is little agreement about the optimum solid feed strategies for preweaned calves. Use of fibrous feeds has been discouraged because of the limited use of cellulose during the preweaning period, and because the accumulation of undigested forage material in the rumen could decrease voluntary intake of concentrate (Drackley, 2008). On the other hand, when chopped grass hay or grass silages were offered to young dairy calves during the pre- and postweaning periods separately from the starter feed, calves consumed a low amount of forage, but it was sufficient to foster an increase in concentrate intake and improving ADG (Castells et al. 2012). Similarly, Thomas and Hinks (1982) have shown improvements in performance when offering barley straw, and Khan et al. (2011) reported increases in total solid feed intake and physical development of the reticulorumen when orchard grass hay was fed. In contrast, when the forage fed is alfalfa hay, these benefits have not been observed (Castells et al., 2012). Although there is a positive effect of the inclusion of forage (other than alfalfa) in the diet of young calves, the potential mechanisms that elicit improvements of DMI and ADG are not clear. Castells et al. (2012) hypothesized that the increased intake observed in calves offered forage could be due to an improvement of the rumen environment. Furthermore, Khan et al. (2011) found that calves offered forage presented greater rumen liquid $\mathrm{pH}$ compared with those calves fed no forage. Similarly, Thomas and Hinks (1982) reported a positive relationship between postweaning intake and rumen liquid $\mathrm{pH}$, and highlighted the importance of rumen liquid $\mathrm{pH}$ on explaining variations in concentrate intake.

The objective of this study was to investigate some potential factors related to rumen and gastrointestinal tract (GIT) development that may be involved in intake regulation of young calves when a grass or legume forage is offered.

\section{MATERIALS AND METHODS}

\section{Animals and Treatments}

Received November 26, 2012.

Accepted April 16, 2013.

${ }^{1}$ Corresponding author: marta.terre@irta.cat
Fifteen male Holstein calves were purchased from commercial farms and raised at the facilities of IRTA 
Table 1. Ingredient and chemical composition (as \% of DM) of experimental starter feed and forages

\begin{tabular}{|c|c|c|c|}
\hline Item & Concentrate & Alfalfa hay & Oat hay \\
\hline \multicolumn{4}{|l|}{ Ingredient } \\
\hline Wheat & 20.0 & - & - \\
\hline Corn & 15.0 & - & - \\
\hline Barley & 11.2 & - & - \\
\hline Sorghum & 12.0 & - & - \\
\hline Soybean meal & 23.0 & - & - \\
\hline Wheat middlings & 12.0 & - & - \\
\hline Soybean hulls & 5.0 & - & - \\
\hline Premix $^{1}$ & 0.2 & - & - \\
\hline Calcium carbonate & 0.5 & - & - \\
\hline Dicalcium phosphate & 0.3 & - & - \\
\hline Sodium chloride & 0.8 & - & - \\
\hline \multicolumn{4}{|l|}{ Nutrient composition } \\
\hline CP & 20.4 & 17.0 & 9.7 \\
\hline $\mathrm{NDF}$ & 21.1 & 47.9 & 72.1 \\
\hline $\mathrm{ADF}$ & 9.8 & 41.8 & 46.2 \\
\hline Ash & 5.0 & 7.1 & 7.1 \\
\hline
\end{tabular}

${ }^{1}$ Premix composition: vitamin A 2,007,000 IU $/ \mathrm{kg}$; vitamin $\mathrm{D}_{3} 433,000 \mathrm{IU} / \mathrm{kg}$; vitamin $\mathrm{E}_{3} 685 \mathrm{mg} / \mathrm{kg}$; vitamin $\mathrm{B}_{1} 52 \mathrm{mg} / \mathrm{kg}$; vitamin $\mathrm{B}_{2} 197 \mathrm{mg} / \mathrm{kg}$; vitamin $\mathrm{B}_{6} 98 \mathrm{mg} / \mathrm{kg}$; vitamin $\mathrm{B}_{12} 0.76 \mathrm{mg} / \mathrm{kg}$; vitamin $\mathrm{K}_{3} 52 \mathrm{mg} / \mathrm{kg}$; nicotinic acid $656 \mathrm{mg} / \mathrm{kg}$; pantothenic acid $394 \mathrm{mg} / \mathrm{kg} ; \mathrm{Mn} 5,877 \mathrm{mg} / \mathrm{kg} ; \mathrm{Fe}$ 7,093 mg/kg; Cu 2,026 mg/kg; Co $46 \mathrm{mg} / \mathrm{kg} ; \mathrm{Zn} 8,112 \mathrm{mg} / \mathrm{kg}$; I $304 \mathrm{mg} / \mathrm{kg} ;$ Se $46 \mathrm{mg} / \mathrm{kg}$.

(El Prat, Spain). Calves were managed according to the recommendations of the Animal Care Committee of IRTA, and had the approval of national animal care committee (number 6271). After arrival, calves were given a broad-spectrum antibiotic (Draxxin, tulathromycin, Pfizer Animal Health, Madrid, Spain) to minimize respiratory disease. Calves were also vaccinated against respiratory syncytial virus (Rispoval RS, Pfizer Animal Health) 3 d after arrival. Calves were housed in individual wooden pens $(2.0 \times 1.55 \mathrm{~m})$ and bedded with sawdust in a barn with forced ventilation. The study began when calves were $8.3 \pm 2.96 \mathrm{~d}$ old and $43.7 \pm 4.39 \mathrm{~kg}$ of $\mathrm{BW}$. Animals were stratified according to $\mathrm{BW}$ and age in 3 groups. Calves in the control (CON) group were fed a starter concentrate (pelleted) without any forage supplementation until the end of the study. Calves in the other 2 treatments were offered the same starter concentrate as the CON group plus a source of chopped forage fed separately (Table 1). Forages were either chopped alfalfa $(\mathbf{A H})$ or chopped oat hay $(\mathbf{O H})$. Forages were chopped (particle size distribution measured with 2 sieves with openings of 20 and $8 \mathrm{~mm}: 38.4 \%>20 \mathrm{~mm}, 16.9 \%$ between 8 and $20 \mathrm{~mm}$, and $44.7 \%<8 \mathrm{~mm}$ for alfalfa hay; and $27.5 \%$ $>20 \mathrm{~mm}, 26.3 \%$ between 8 and $20 \mathrm{~mm}$, and $46.2 \%<8$ $\mathrm{mm}$ for oat hay) with a forage-chopper machine (Seko, Curtarolo, Italy). Calves were fed milk replacer (MR; 25\% CP and $19.2 \%$ fat, Sprayfo Excellent 60, Sloten BV, Deventer, the Netherlands) at $12.5 \%$ DM dilution rate. Calves received $4 \mathrm{~L}$ of $\mathrm{MR}$ at $12.5 \% \mathrm{DM}$ dilution rate until $50 \mathrm{~d}$ of age. From 50 to $56 \mathrm{~d}$ of age, calves received only the morning feeding of $2 \mathrm{~L}$ at $12.5 \%$. Ani- mals were weaned at $57 \mathrm{~d}$ of age and the study ended 3 wk after weaning.

\section{Measurements and Sample Collection}

Starter feed, MR, and forage intakes were recorded daily on an individual basis. Body weight was recorded weekly. A sample of rumen liquid was taken using an oral tube every week. A $50-\mathrm{mL}$ subsample was immediately frozen to $-80^{\circ} \mathrm{C}$ for subsequent bacteria population analyses. The remainder of the sample was filtered through 2 layers of cheesecloth, and the $\mathrm{pH}$ was immediately measured with a $\mathrm{pH}$ meter (Crison pH25, Barcelona, Spain). Also, $4 \mathrm{~mL}$ of the filtered rumen liquid was mixed with $1 \mathrm{~mL}$ of solution containing $2 \mathrm{~g} / \mathrm{L}$ of mercuric chloride, $20 \mathrm{~mL} / \mathrm{L}$ orthophosphoric acid, and $2 \mathrm{~g} / \mathrm{L}$ of 4-methylvaleric (internal standard) in distilled water and stored at $-20^{\circ} \mathrm{C}$ to analyze concentrations of VFA.

Total GIT passage rate was estimated 2 wk after weaning using chromic oxide as an external marker. Animals were orally dosed before the morning concentrate offer with a single dose of $2 \mathrm{~g}$ of chromic oxide in a gelatin capsule, and fecal grab samples were taken at $4,8,12,16,20,24,28,32,48,56,72,80,96$, and $120 \mathrm{~h}$ after dosing. Fecal samples were frozen immediately after collection for subsequent chromium determination.

Finally, 3 wk after weaning, between 0800 and 1100 h, calves were euthanized following the European Guidelines for Animal Welfare (Directive 86/609 EEC) with an intravenous injection $(200 \mathrm{mg} / \mathrm{kg}$ of $\mathrm{BW})$ of pentobarbital (Dolethal, Vetoquinol, Lure, France). 
The abdomen was opened and each individual anatomical part (rumen, reticulum, omasum, abomasum, duodenum, jejunum, ileum, cecum, colon, rectum) of the GIT was separated and weighed. Then, the contents of each section were collected and weighed, and the respective GIT parts were weighed again to determine mucosal empty weight. The $\mathrm{pH}$ of the content of each individual part of the GIT was measured. Samples from the dorsal sac of the rumen and parotid gland tissue were taken after death and preserved in RNAlater solution (Ambion, Austin, TX) for subsequent analysis of mRNA gene expression. Additionally, a sample of rumen content was obtained to determine DM and buffering capacity. Furthermore, homogenized samples of rumen and cecum contents were obtained to analyze viscosity and bacterial populations. Samples taken for the analysis of bacterial population were immediately frozen to $-80^{\circ} \mathrm{C}$ and stored until subsequent analysis. Moreover, 4-mL samples from the cecum contents were immediately acidified with $1 \mathrm{~mL}$ of a solution containing $2 \mathrm{~g} / \mathrm{L}$ mercuric chloride, $20 \mathrm{~mL} / \mathrm{L}$ orthophosphoric acid, and $2 \mathrm{~g} / \mathrm{L}$ 4-methylvaleric (internal standard) in distilled water, and stored at $-20^{\circ} \mathrm{C}$ for subsequent VFA analyses. Tissue samples from the cranio-dorsal rumen wall were excised and preserved by immersion in 10\% (vol:vol) phosphate-buffered formalin for histomorphometric analysis.

\section{Analytical Procedures}

Samples of starter, forage, and MR were analyzed for $\mathrm{DM}\left(24 \mathrm{~h}\right.$ at $\left.103^{\circ} \mathrm{C}\right)$, ash $\left(4 \mathrm{~h}\right.$ at $\left.550^{\circ} \mathrm{C}\right), \mathrm{N}$ content, ether extract, NDF, and ADF. Nitrogen content was measured using the AOAC (1990) method (method 988.05) adapted for an automatic distiller Kjeldahl (Kjeltec Auto 1030 Analyzer, Tecator, Hoganas, Sweden) with copper sulfate/selenium as a catalyst instead of copper sulfate/titanium dioxide. Ether extract was measured using the AOAC method (method 920.39) using petroleum ether for distillation instead of diethyl ether (AOAC, 1990). NDF was analyzed with sodium sulfite and heat-stable $\alpha$-amylase (Van Soest et al., 1991), and ADF following the AOAC (1990) method (method 973.18). The content of VFA in the ruminal fluid was analyzed by gas chromatography (HP-6890 Series II Agilent, Hewlett Packard, Palo Alto, CA) using a capillary column $(10 \mathrm{~m} \times 0.10 \mathrm{~mm} \times 100 \mu \mathrm{m}$; DB5, Agilent, Palo Alto, CA). The determination of chrome concentration in feces was conducted by atomic absorption spectrophotometry according to the method described by Williams et al. (1962).

Total RNA from ruminal and salivary gland tissue samples was extracted using Trizol (Invitrogen, Pais- ley, UK). One microgram of RNA was retrotranscribed to cDNA using IScript cDNA synthesis kit (Bio-Rad, Hercules, CA) following the manufacturer's instructions. Real-time PCR was performed using specific primers. Primers were designed either using the Vector NTI Advance software package (Invitrogen) or using primers previously reported in the literature (Table 2). The target genes were monocarboxylate transporter 1 (MCT1), monocarboxylate transporter 4 (MCT4), downregulated in adenoma $(\boldsymbol{D R} \boldsymbol{A}), \mathrm{Na}^{+} / \mathrm{H}^{+}$exchange 1 and 3 (NHE1 and $\boldsymbol{N H E 3 ) , ~ a n d ~ s p i n d l e ~ p o l e ~ b o d y ~}$ component 25 (SPC25) for rumen tissue, and aquaporin-5 (AQ5), and calcium activated chloride channel (TMEM16) for parotid gland tissue. A total reaction volume of $20 \mu \mathrm{L}$ was used, containing $100 \mathrm{ng}$ of cDNA, $10 \mu \mathrm{L}$ of SYBR Green (Bio-Rad Laboratories), and the optimized primer concentration for each gene (Table 2 ). The PCR reactions were conducted using a thermocycler iCycler (Bio-Rad) and cycled as follows: an initial denaturing step of $10 \mathrm{~min}$ at $95^{\circ} \mathrm{C}$, followed by 40 cycles of $10 \mathrm{~s}$ at $95^{\circ} \mathrm{C}, 15 \mathrm{~s}$ at optimized annealing temperature for each gene, $30 \mathrm{~s}$ at $72^{\circ} \mathrm{C}$, and a final extension of $5 \mathrm{~min}$ at $72^{\circ} \mathrm{C}$. Gene expression values were evaluated using the delta cycle threshold $\left(\Delta \mathrm{C}_{\mathrm{t}}\right)$ method with $\beta$-actin as the housekeeping gene.

To study rumen microbiota, samples of ruminal content were thawed and centrifuged at $6,654 \times g$ for 15 min. Supernatant was discarded, the pellet homogenized, and a subsample of $0.25 \mathrm{~g}$ was weighed. From each sample, DNA was extracted by bead-beating in the presence of high concentrations of sodium dodecyl sulfate, salt, and EDTA, and with subsequent DNA purification by QIAmp DNA Stool Mini Kit columns (Qiagen, Hilden, Germany; Yu and Morrison, 2004). Real-time PCR was performed using specific primers. Primers were designed using the Vector NTI Advance software package (Table 2). Microorganisms evaluated were Streptococcus bovis and Ruminococcus albus. A total reaction volume of $20 \mu \mathrm{L}$ containing $100 \mathrm{ng}$ of cDNA, $10 \mu \mathrm{L}$ of SYBR Green (Bio-Rad Laboratories), and the optimized primer concentration for each gene (see Table 2) was used. The PCR reactions were conducted using a thermocycler iCycler (Bio-Rad Laboratories) and cycled as follows: an initial denaturing step of $10 \mathrm{~min}$ at $95^{\circ} \mathrm{C}$, followed by 40 cycles of $30 \mathrm{~s}$ at $95^{\circ} \mathrm{C}$, $10 \mathrm{~s}$ at optimized annealing temperature for each gene, $30 \mathrm{~s}$ at $72^{\circ} \mathrm{C}$, and a final extension of $5 \mathrm{~min}$ at $72^{\circ} \mathrm{C}$.

Buffering capacity was measured according to Tucker et al. (1992). Viscosity was measured in ruminal and cecal samples after centrifugation at $12,000 \times g$ for 10 min. The supernatant was withdrawn and the viscosity was determined using a Brookfield Digital DV-II cone/ plate viscometer (Brookfield Engineering Laboratories 
Table 2. Gene names, primer sequences $(\mathrm{F}=$ forward, $\mathrm{R}=$ reverse), annealing temperature $(\mathrm{Tm})$, primer concentration, and references of the used genes

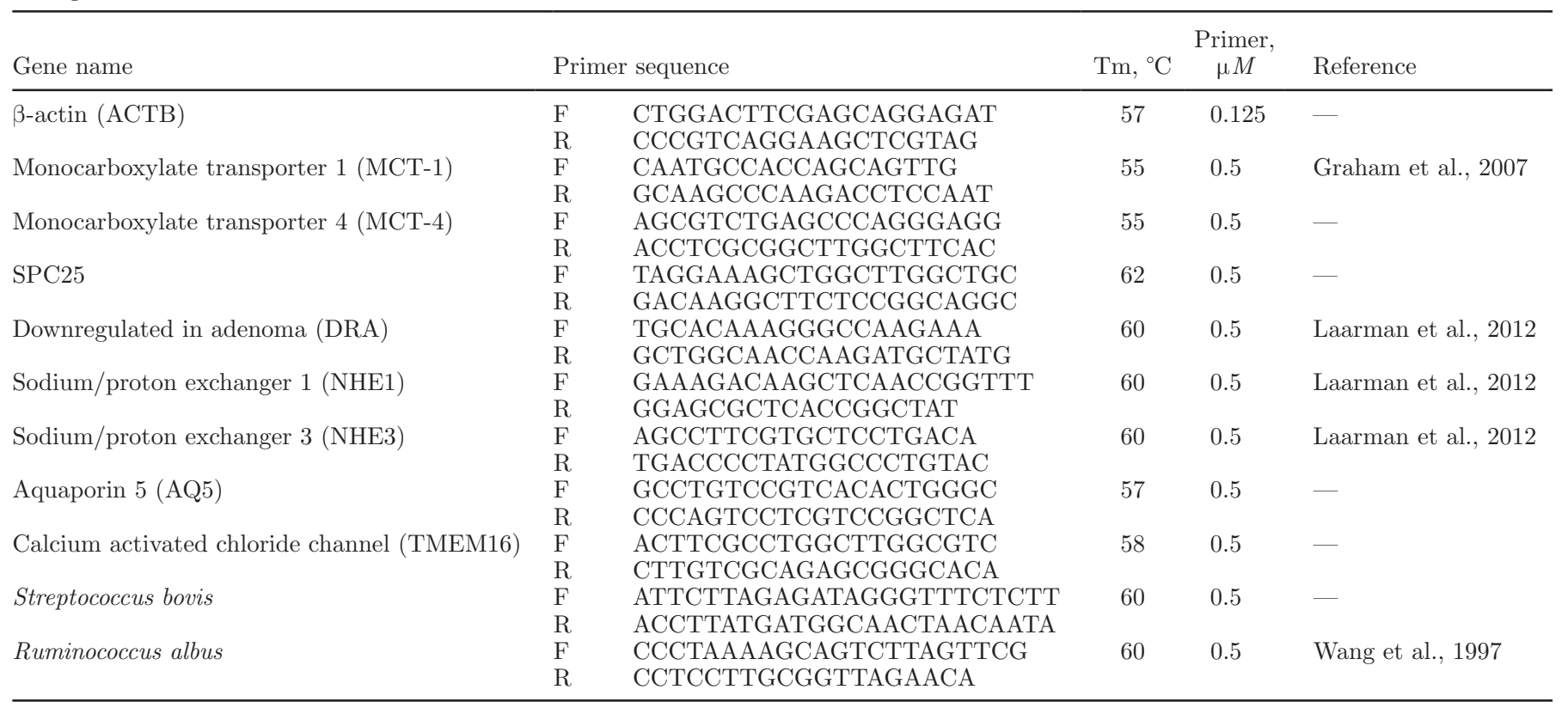

Inc., Middleboro, MA) maintained at $30^{\circ} \mathrm{C}$ and a shear rate of 12 to $60 \mathrm{~s}^{-1}$. Absolute viscosity at a shear rate of $60 \mathrm{~s}^{-1}$ is presented.

Tissue samples for the histological morphometric study were dehydrated and embedded in paraffin wax, sectioned at $4 \mathrm{~mm}$ and stained with hematoxylin and eosin. Morphometric measurements were performed with an optical microscope (BHS, Olympus, Hamburg, Germany) using a grid ocular (Microplanet, Olympus). Rumen papillae height and width, keratin layer, and muscular width were measured on all well-oriented rumen papillae. All morphometric measurements were performed by the same person, who had no prior knowledge of the correspondence between samples and treatments.

\section{Statistical Analysis}

Data from performance and rumen parameters were analyzed using a mixed-effects model for repeated measures. The statistical model included treatment, time (week of study), and their interaction as fixed effects, and animal within treatment as a random effect. Compound symmetry was used as variance-covariance structure. All statistical analyses were performed with SAS software (version 9.2; SAS Inst. Inc., Cary, NC).

Fractional rate of passage in the rumen $\left(\boldsymbol{k}_{r}\right)$ and cecum $\left(\boldsymbol{k}_{\boldsymbol{c}}\right)$, transit time (TT) in the tubular compartment of the GIT, and total mean retention time (TMRT) of the marker in the GIT were calculated according to the multicompartmental model proposed by Dhanoa et al. (1985). Fractional rate of passage, TT, TMRT, and data obtained from slaughtered animals were analyzed using an ANOVA with treatment as main effect.

\section{RESULTS AND DISCUSSION}

\section{Performance}

Animal performance and feed consumption are presented in Table 3. During the preweaning period, starter concentrate intake did not differ among treatments. Forage intake was greater $(P=0.01)$ in $\mathrm{AH}$ compared with $\mathrm{OH}$ calves. In spite of the additional forage consumption of $\mathrm{AH}$ and $\mathrm{OH}$ animals, total dry matter intake (TDMI) did not differ among treatments. Similarly to concentrate intake, ADG did not differ and the gain-to-feed ratio was also similar among treatments. During the postweaning period, intake results were similar to those observed during the preweaning period. Calves had similar starter intake among treatments, and AH calves consumed more forage than calves in $\mathrm{OH}$ treatment. However, during the postweaning period, $\mathrm{OH}$ animals tended $(P=0.07)$ to grow more than $\mathrm{AH}$ and $\mathrm{CON}$ animals.

Previous studies (Thomas and Hinks, 1982; Castells et al., 2012) have shown an increase in concentrate intake and growth performance in young calves supplemented with forage. In the present study, even no differences were observed among treatments, animals fed forage had a numerically greater concentrate intake and BW gain compared with animals without access to a for- 
Table 3. Performance and feed intake of calves supplemented with alfalfa $(\mathrm{AH})$ or oat hay $(\mathrm{OH})$, or not supplemented (CON)

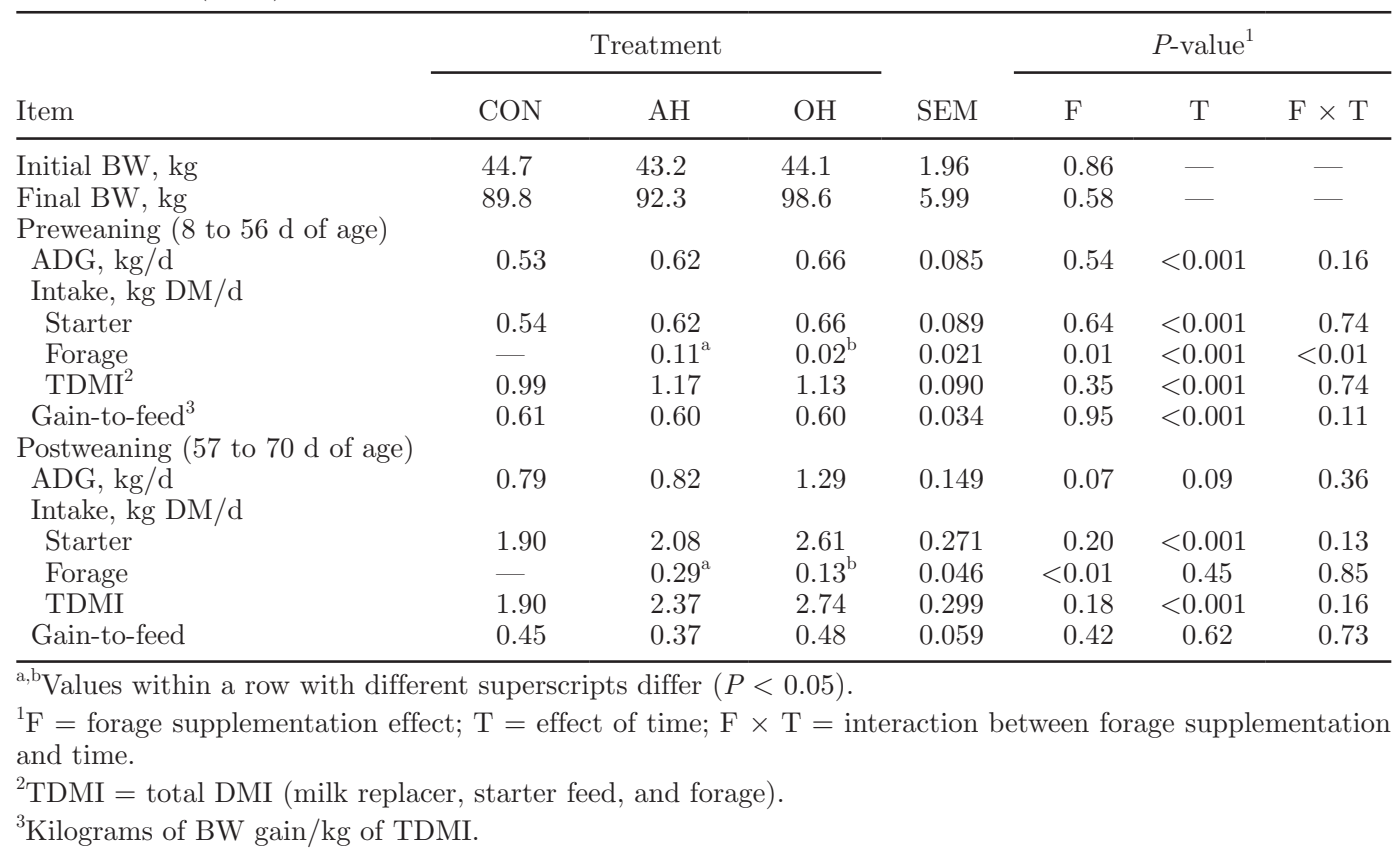

age source. The lack of significant results was probably because of the low number of animals used in this study (the objective was not to evaluate differences in performance but in GIT parameters). On the other hand, the greater consumption of $\mathrm{AH}$ was expected because voluntary intake of legumes is usually greater than that of grasses (Colburn et al., 1968; Moseley and Jones, 1979).

\section{Rumen Fermentation Parameters}

Total VFA concentrations and individual proportions of VFA, as well as pH of ruminal liquid, are presented in Table 4. Animals supplemented with a forage source presented a greater $(P<0.01)$ rumen liquid $\mathrm{pH}$ compared with CON calves. On the other hand, CON animals showed the greatest $(P<0.05)$ total rumen VFA concentration from the week before the weaning to the end of the study. Calves receiving the $\mathrm{AH}$ treatment presented a different VFA fermentation profile compared with the other treatments. Rumen acetate proportions in $\mathrm{AH}$ calves increased $(P<0.01)$ from wk 3 to 6 at the expenses of valerate, which was lesser in the rumen liquid of $\mathrm{AH}$ calves than in that of calves in other treatments throughout the study. Furthermore, the acetate:propionate ratio tended $(P=0.09)$ to be greater in CON animals the first week of the study and in $\mathrm{AH}$ calves at $6 \mathrm{wk}$ compared with the other treatments.

We found no differences in the abundance of Streptococcus bovis in the rumen among treatments throughout the study, whereas the population of Ruminococcus albus increased $(P<0.05)$ in $\mathrm{AH}$ compared with $\mathrm{OH}$ animals in wk 6 of the study (Table 4 ).

Similar to the current study, an increase of rumen $\mathrm{pH}$ when forage was included in the diet of young calves has been previously reported in the literature (Thomas and Hinks 1982; Khan et al., 2011). In contrast to these studies, Suárez et al. (2007) did not find any difference in rumen $\mathrm{pH}$ when part of the concentrate was replaced by forage. Values for ruminal VFA concentrations in the current experiment are in the range previously reported in the literature (Coverdale et al., 2004; Suárez et al., 2007), and a negative correlation between rumen VFA concentration and rumen liquid $\mathrm{pH}$ was observed $\left(\mathrm{R}^{2}=0.50, P<0.05\right)$. Results reported herein are in accordance with Coverdale et al. (2004), who found an increase in ruminal VFA concentration (and decrease in rumen $\mathrm{pH}$ ) in animals fed only concentrate compared with those fed concentrate plus a fixed proportion of hay. In contrast, Suárez et al. (2007) and Thomas and Hinks (1982), who offered different forage presentations to young calves, did not observe differences in total rumen VFA concentrations compared with non-forage-fed calves. Furthermore, rumen valerate molar concentrations in the current study were lowest in $\mathrm{AH}$ calves. Cline et al. (1958) described a positive relationship between numbers of cellulolytic rumen microbes and the rate of valerate utilization in the rumen. Although differences in $R$. albus, a cellulolytic bacteria, could not be described in the present study, the lower valerate proportion in $\mathrm{AH}$ might suggest improved growth of cellulolytic bacteria in calves supplemented with $\mathrm{AH}$. 
Table 4. Ruminal pH, total VFA concentration, individual molar proportion of VFA, and bacterial populations from weekly samples of rumen liquid from calves supplemented with alfalfa hay (AH), oat hay (OH), or not supplemented (CON)

\begin{tabular}{|c|c|c|c|c|c|c|c|}
\hline \multirow[b]{2}{*}{ Item } & \multicolumn{3}{|c|}{ Treatment } & \multirow[b]{2}{*}{ SEM } & \multicolumn{3}{|c|}{$P$-value ${ }^{1}$} \\
\hline & $\mathrm{CON}$ & $\mathrm{AH}$ & $\mathrm{OH}$ & & $\mathrm{F}$ & $\mathrm{T}$ & $\mathrm{F} \times \mathrm{T}$ \\
\hline $\mathrm{pH}$ & $5.50^{\mathrm{b}}$ & $6.36^{\mathrm{a}}$ & $6.00^{\mathrm{a}}$ & 0.160 & $<0.01$ & $<0.05$ & 0.61 \\
\hline Total VFA, $\mathrm{m} M$ & $139.6^{\mathrm{a}}$ & $109.4^{\mathrm{b}}$ & $101.5^{\mathrm{b}}$ & 4.98 & $<0.001$ & $<0.001$ & $<0.05$ \\
\hline $\begin{array}{l}\text { VFA, mol/100 mol } \\
\text { Acetate }\end{array}$ & $46.7^{\mathrm{ab}}$ & $51.8^{\mathrm{a}}$ & $46.1^{\mathrm{b}}$ & 1.91 & 0.10 & $<0.001$ & $<0.01$ \\
\hline Propionate & 31.7 & 34.0 & 34.0 & 2.09 & 0.68 & $<0.001$ & 0.13 \\
\hline Butyrate & 15.1 & 9.9 & 14.4 & 1.77 & 0.12 & $<0.001$ & 0.18 \\
\hline Isobutyrate & 0.9 & 0.9 & 0.9 & 0.15 & 0.98 & $<0.001$ & 0.51 \\
\hline Valerate & $5.5^{\mathrm{a}}$ & $2.8^{\mathrm{b}}$ & $4.4^{\mathrm{ab}}$ & 0.62 & $<0.05$ & 0.05 & 0.13 \\
\hline Isovalerate & 0.9 & 0.9 & 0.7 & 0.15 & 0.75 & $<0.001$ & 0.42 \\
\hline $\mathrm{C} 2: \mathrm{C} 3$ & 1.8 & 1.7 & 1.5 & 0.16 & 0.47 & $<0.001$ & 0.09 \\
\hline Streptococcus bovis ${ }^{2}$ & 32.5 & 32.1 & 32.4 & 0.33 & 0.64 & 0.69 & 0.78 \\
\hline Ruminococcus albus ${ }^{2}$ & 28.8 & 25.6 & 28.1 & 1.97 & 0.49 & 0.31 & $<0.05$ \\
\hline
\end{tabular}

$\overline{\mathrm{a}, \mathrm{b}}$ Values within a row with different superscripts differ $(P<0.05)$ or tend to differ $(P<0.10)$.

${ }^{1} \mathrm{~F}=$ forage supplementation effect; $\mathrm{T}=$ effect of time; $\mathrm{F} \times \mathrm{T}=$ interaction between forage supplementation and time.

${ }^{2}$ Cycle threshold values (smaller numerical values indicate greater abundance).

Results regarding rumen bacteria populations herein are in agreement with those reported by Petri et al. (2012), who did not find differences in abundance of Streptococcus bovis and Ruminococcus spp. between animals fed a high concentrate diet with or without forage inclusion, probably because Ruminococcus spp. are able to use starch as a substrate.

\section{Gastrointestinal Passage Rate}

Results pertaining to the external marker GIT passage rate are shown in Table 5. Animals in the $\mathrm{OH}$ treatment had the greatest $(P<0.05)$ ruminal fractional passage rate of the marker. We found no differences in the marker fractional rate of passage in the cecum $\left(k_{c}\right)$ and TT in the tubular compartment of the GIT. However, TMRT of the marker in the GIT tended $(P=$ 0.07 ) to be lesser in $\mathrm{OH}$ than in $\mathrm{CON}$ animals.

Differences in the marker GIT passage rate among treatments observed herein may be explained, in part, by the numerically greater concentrate intake observed in $\mathrm{OH}$ calves, because, generally, greater DM intake results in a greater passage rate (Huhtanen and Kukkonen, 1995). Although ruminal passage rate of legumes is described to be usually greater than that of grasses, because particle breakdown of legumes makes legumes to pass easily through the rumen (Moseley and Jones, 1984; McLeod et al., 1990), it also contributes to increased legume forage intake, as observed in the present study. Therefore, the greater forage consumption in $\mathrm{AH}$ compared with $\mathrm{OH}$ treatments may explain the differences between these 2 treatments (and the similarity between $\mathrm{AH}$ and $\mathrm{CON}$ calves), because rate of passage of high- versus low-forage diets entails a decrease in fractional passage rate from the rumen (Voelker-Linton and Allen, 2007).

\section{Slaughter Data}

Empty body weight (EBW) expressed as percentage of live BW tended $(P=0.08)$ to be greater in $\mathrm{OH}$ and CON compared with AH calves (Table 6). Full total

Table 5. Fractional rates of passage, transit time (TT), and total mean retention time (TMRT) of the external marker in the gastrointestinal tract of calves supplemented with alfalfa hay (AH), oat hay $(\mathrm{OH})$, or not supplemented $(\mathrm{CON})$

\begin{tabular}{|c|c|c|c|c|c|}
\hline \multirow[b]{2}{*}{ Item $^{1}$} & \multicolumn{3}{|c|}{ Treatment $^{1}$} & \multirow[b]{2}{*}{ SEM } & \multirow[b]{2}{*}{$P$-value } \\
\hline & $\mathrm{CON}$ & $\mathrm{AH}$ & $\mathrm{OH}$ & & \\
\hline $\mathrm{k}_{\mathrm{r}}, \mathrm{h}^{-1}$ & $0.070^{\mathrm{b}}$ & $0.082^{\mathrm{b}}$ & $0.147^{\mathrm{a}}$ & 0.0187 & $<0.05$ \\
\hline $\mathrm{k}_{\mathrm{c}}, \mathrm{h}^{-1}$ & 0.667 & 1.030 & 1.009 & 0.3558 & 0.73 \\
\hline TT, h & 10.25 & 7.42 & 9.57 & 1.029 & 0.18 \\
\hline TMRT, h & $28.36^{\mathrm{a}}$ & $22.76^{\mathrm{ab}}$ & $18.84^{\mathrm{b}}$ & 2.703 & 0.07 \\
\hline
\end{tabular}

$\overline{a, b}$ Values within a row with different superscripts differ $(P<0.05)$.

${ }^{1} \mathrm{k}_{\mathrm{r}}=$ fractional rate of passage in the rumen; $\mathrm{k}_{\mathrm{c}}=$ fractional rate of passage in the cecum. 
Table 6. Body weight and viscera weights at slaughter of calves supplemented with alfalfa hay (AH), oat hay $(\mathrm{OH})$, or not supplemented $(\mathrm{CON})$

\begin{tabular}{|c|c|c|c|c|c|}
\hline \multirow[b]{2}{*}{ Item $^{1}$} & \multicolumn{3}{|c|}{ Treatment } & \multirow[b]{2}{*}{ SEM } & \multirow[b]{2}{*}{$P$-value } \\
\hline & $\mathrm{CON}$ & $\mathrm{AH}$ & $\mathrm{OH}$ & & \\
\hline Slaughter BW, kg & 89.8 & 92.3 & 98.6 & 5.99 & 0.58 \\
\hline EBW & 68.8 & 68.8 & 81.5 & 4.79 & 0.19 \\
\hline $\mathrm{EBW}, \%$ of $\mathrm{BW}$ & $76.7^{\mathrm{a}}$ & $74.5^{\mathrm{b}}$ & $76.9^{\mathrm{a}}$ & 0.75 & 0.08 \\
\hline Liver, $\mathrm{kg}$ & 2.23 & 2.50 & 2.48 & 0.087 & 0.15 \\
\hline Liver, $\%$ of BW & $2.38^{\mathrm{b}}$ & $2.69^{\mathrm{a}}$ & $2.64^{\mathrm{ab}}$ & 0.097 & 0.10 \\
\hline Spleen, kg & $0.47^{\mathrm{ab}}$ & $0.40^{\mathrm{b}}$ & $0.53^{\mathrm{a}}$ & 0.038 & 0.08 \\
\hline Spleen, \% of BW & $0.51^{\mathrm{ab}}$ & $0.42^{\mathrm{b}}$ & $0.57^{\mathrm{a}}$ & 0.043 & 0.09 \\
\hline TGIT full, kg & $19.5^{\mathrm{ab}}$ & $21.2^{\mathrm{a}}$ & $18.3^{\mathrm{b}}$ & 0.77 & 0.08 \\
\hline TGIT full, $\%$ of BW & $20.5^{\mathrm{ab}}$ & $22.5^{\mathrm{a}}$ & $19.6^{\mathrm{b}}$ & 0.82 & 0.08 \\
\hline TGIT empty, kg & 7.7 & 7.8 & 7.7 & 0.29 & 0.96 \\
\hline TGIT empty, $\%$ of BW & 8.0 & 8.3 & 8.1 & 0.29 & 0.83 \\
\hline Rumen full, $\mathrm{kg}$ & 10.0 & 10.2 & 9.0 & 1.10 & 0.74 \\
\hline Rumen full, $\%$ of BW & 10.6 & 10.8 & 9.8 & 1.16 & 0.83 \\
\hline Rumen empty, kg & $2.80^{\mathrm{a}}$ & $2.37^{\mathrm{ab}}$ & $2.08^{\mathrm{b}}$ & 0.205 & 0.08 \\
\hline Rumen empty, $\%$ of BW & 2.9 & 2.5 & 2.2 & 0.22 & 0.15 \\
\hline Abomasum, full, $\mathrm{kg}$ & 1.11 & 1.62 & 1.43 & 0.215 & 0.23 \\
\hline Abomasum full, $\%$ of BW & 1.1 & 1.7 & 1.5 & 0.22 & 0.13 \\
\hline Abomasum empty, kg & $0.52^{\mathrm{b}}$ & $0.58^{\mathrm{ab}}$ & $0.63^{\mathrm{a}}$ & 0.027 & $<0.05$ \\
\hline Abomasum empty, $\%$ of BW & $0.5^{\mathrm{b}}$ & $0.6^{\mathrm{ab}}$ & $0.7^{\mathrm{a}}$ & 0.03 & $<0.05$ \\
\hline \multicolumn{6}{|l|}{$\%$ of TGIT } \\
\hline Rumen full & 52.6 & 47.8 & 42.2 & 3.93 & 0.29 \\
\hline Rumen empty & $35.9^{\mathrm{a}}$ & $30.4^{\mathrm{ab}}$ & $27.3^{\mathrm{b}}$ & 2.34 & 0.07 \\
\hline Abomasum full & 5.4 & 8.0 & 7.6 & 1.2 & 0.26 \\
\hline Abomasum empty & $6.8^{\mathrm{b}}$ & $7.3^{\mathrm{ab}}$ & $8.2^{\mathrm{a}}$ & 0.37 & 0.05 \\
\hline \multicolumn{6}{|l|}{$\%$ of EBW } \\
\hline Rumen full & 14.0 & 14.6 & 10.9 & 1.45 & 0.26 \\
\hline Rumen empty & 3.7 & 3.4 & 2.8 & 0.31 & 0.17 \\
\hline Abomasum full & $1.3^{\mathrm{b}}$ & $2.3^{\mathrm{a}}$ & $2.2^{\mathrm{ab}}$ & 0.32 & 0.10 \\
\hline Abomasum empty & $0.70^{\mathrm{b}}$ & $0.83^{\mathrm{a}}$ & $0.86^{\mathrm{a}}$ & 0.042 & $<0.05$ \\
\hline
\end{tabular}

${ }_{\mathrm{a}, \mathrm{b}}$ Numerical values within a row with different superscripts differ $(P<0.05)$ or tend to differ $(P<0.10)$.

${ }^{1} \mathrm{EBW}=$ empty $\mathrm{BW} ; \mathrm{TGIT}=$ total gastrointestinal tract; $\mathrm{EBW}=\mathrm{BW}-\mathrm{TGIT}-$ Liver - Spleen.

gastrointestinal tract (TGIT) weight tended $(P=$ 0.08 ) to be greater in $\mathrm{AH}$ than in $\mathrm{OH}$ animals, but no differences were observed in TGIT tissue weight among treatments. Rumen tissue of $\mathrm{CON}$ animals tended $(P=$ $0.08)$ to be heavier and tended $(P=0.07)$ to represent a greater proportion of the TGIT than in OH calves. On the other hand, the weight of the abomasum tissue and its proportion relative to total BW and EBW, or TGIT weight of $\mathrm{OH}$ animals was greater $(P<0.05)$ than in CON animals. Finally, no differences were found in midgut or hindgut weights among treatments (data not shown). Spleen tended $(P=0.08)$ to weigh more and tended $(P=0.09)$ to represent a greater proportion of $\mathrm{BW}$ in $\mathrm{OH}$ animals than in $\mathrm{AH}$ animals, and liver of $\mathrm{AH}$ calves tended $(P=0.10)$ to represent a greater proportion of $\mathrm{BW}$ than that of $\mathrm{CON}$ animals.

The rumen liquid $\mathrm{pH}$ for the different GIT contents and the VFA concentrations of the cecum at slaughter are presented in Table 7 . Rumen liquid $\mathrm{pH}$ did not differ among treatments at slaughter. However, animals in CON treatment tended $(P=0.07)$ to present a greater jejunum liquid $\mathrm{pH}$ compared with $\mathrm{OH}$ animals. Furthermore, ileum $\mathrm{pH}$ tended $(P=0.09)$ to be greatest in $\mathrm{AH}$ calves, and rectum $\mathrm{pH}$ was lowest $(P<0.05)$ in $\mathrm{OH}$ animals. Although no differences in cecum $\mathrm{pH}$ were observed, cecum VFA concentrations tended $(P=0.08)$ to be greater in forage-fed than in $\mathrm{CON}$ animals, and cecum $\mathrm{pH}$ and VFA concentrations were moderately correlated $\left(\mathrm{R}^{2}=0.72, P<0.05\right)$. Cecum individual VFA molar proportions were similar among treatments, with the exception of acetate that was greatest in CON calves. On the other hand, we observed no differences among treatments in rumen DM content, rumen buffering capacity, or rumen and cecum viscosity.

Results from rumen histology are presented in Table 8. Calves on the CON treatment presented the rumen papillae with the greatest $(P<0.05)$ length, but no further differences were observed for the rest of histological measures performed. Another parameter recorded was the formation of plaque in the rumen, defined as feed and cell debris sticking to the rumen wall (Suárez et al., 2007). In the present study, the percentage of plaque incidence was 80, 0 , and $0 \%$ for $\mathrm{CON}, \mathrm{AH}$, and $\mathrm{OH}$ animals, respectively. Similarly, Suárez et al. (2007) fed animals an all-concentrate diet and they also observed an increase in rumen tissue weight. Those authors at- 
Table 7. Gastrointestinal pH, and cecum VFA concentrations and proportions at slaughter of calves supplemented with alfalfa hay $(\mathrm{AH})$, oat hay $(\mathrm{OH})$, or not supplemented $(\mathrm{CON})$

\begin{tabular}{|c|c|c|c|c|c|}
\hline \multirow[b]{2}{*}{ Item } & \multicolumn{3}{|c|}{ Treatment } & \multirow[b]{2}{*}{ SEM } & \multirow[b]{2}{*}{$P$-value } \\
\hline & $\mathrm{CON}$ & $\mathrm{AH}$ & $\mathrm{OH}$ & & \\
\hline \multicolumn{6}{|l|}{$\mathrm{pH}$} \\
\hline Rumen & 5.10 & 5.20 & 5.59 & 0.159 & 0.11 \\
\hline Abomasum & 3.42 & 3.11 & 2.75 & 0.278 & 0.28 \\
\hline Duodenum & 5.31 & 5.83 & 5.81 & 0.246 & 0.28 \\
\hline Jejunum & $6.90^{\mathrm{a}}$ & $6.75^{\mathrm{ab}}$ & $6.56^{\mathrm{b}}$ & 0.091 & 0.07 \\
\hline Ileum & $7.03^{\mathrm{b}}$ & $7.78^{\mathrm{a}}$ & $7.09^{\mathrm{b}}$ & 0.200 & 0.09 \\
\hline Cecum & 6.55 & 6.30 & 6.26 & 0.124 & 0.24 \\
\hline Colon & 6.45 & 6.35 & 6.14 & 0.144 & 0.33 \\
\hline Rectum & $6.40^{\mathrm{a}}$ & $6.48^{\mathrm{a}}$ & $5.90^{\mathrm{b}}$ & 0.112 & $<0.01$ \\
\hline Total cecum VFA, mM & $88.7^{\mathrm{b}}$ & $156.1^{\mathrm{a}}$ & $159.1^{\mathrm{a}}$ & 23.03 & 0.08 \\
\hline \multicolumn{6}{|l|}{ Cecum VFA, mol/100 mol } \\
\hline Acetate & $72.0^{\mathrm{a}}$ & $67.0^{\mathrm{b}}$ & $68.7^{\mathrm{ab}}$ & 1.31 & 0.05 \\
\hline Propionate & 18.9 & 21.5 & 20.2 & 1.24 & 0.34 \\
\hline Butyrate & 7.7 & 10.2 & 10.2 & 1.02 & 0.17 \\
\hline Isobutyrate & 0.57 & 0.47 & 0.31 & 0.078 & 0.14 \\
\hline Valerate & 1.01 & 0.88 & 0.72 & 0.228 & 0.69 \\
\hline Isovalerate & 0.36 & 0.32 & 0.21 & 0.083 & 0.45 \\
\hline $\mathrm{C} 2: \mathrm{C} 3$ & 3.82 & 3.22 & 3.44 & 0.246 & 0.24 \\
\hline Rumen DM, \% & 16.8 & 15.7 & 16.6 & 1.18 & 0.78 \\
\hline Rumen buffer capacity, mEq/L & 83.1 & 82.7 & 75.9 & 4.05 & 0.43 \\
\hline Rumen viscosity, $\mathrm{cP}$ & 2.0 & 2.1 & 2.0 & 0.07 & 0.25 \\
\hline Cecum viscosity, $\mathrm{cP}$ & 3.1 & 3.8 & 3.4 & 0.37 & 0.45 \\
\hline
\end{tabular}

${ }^{\mathrm{a}, \mathrm{b}}$ Values within a row with different superscripts differ $(P<0.05)$ or tend to differ $(P<0.10)$.

tributed this increase to a greater plaque formation in those calves fed an all-concentrate diet.

Gene expression of rumen epithelia and quantification of bacterial populations in the rumen and cecum are presented in Table 9 . Animals offered forages tended $(P=0.10)$ to show greater expression of MCT1 transporter than CON animals, and the expression of NHE1 protein tended $(P=0.10)$ to be greater in $\mathrm{AH}$ than in $\mathrm{OH}$ animals. At slaughter, abundance of $S$. bovis and $R$. albus in the rumen and cecum did not differ among treatments (Table 9).

In this study, EBW of $\mathrm{OH}$ calves was about $13 \mathrm{~kg}$ greater than that of CON calves, although this difference did not reach significance (Table 6). Furthermore, $\mathrm{OH}$ calves (which also ended the study with the greatest numerical BW) tended to have the lowest weight of full TGIT and similar empty TGIT than the other treatments, and the EBW as a percentage of total live weight tended to be greatest for $\mathrm{OH}$ and $\mathrm{CON}$ compared with $\mathrm{AH}$ calves. These results indicate that BW gain in $\mathrm{OH}$ calves fed ad libitum was due to an increase in carcass weight rather than an accumulation of digesta in the gastrointestinal tract and thus an increased gut fill, as has been previously hypothesized in the literature (Kertz, 2007; Khan et al., 2012). On the other hand, the numerical increase of BW gain observed in $\mathrm{AH}$ compared with $\mathrm{CON}$ calves was mainly due to a greater weight of the TGIT rather than an increase of carcass weight as occurred in $\mathrm{OH}$ animals, which would suggest an increased gut fill in calves receiving $\mathrm{AH}$. Similarly, a study involving calves fed high volumes of milk and provided with or without long-particle orchardgrass hay, showed no differences in EBW between treatments, but the rumen digesta content was greater

Table 8. Rumen muscular width, papillae length and width, and keratin layer of calves supplemented with alfalfa hay $(\mathrm{AH})$, oat hay $(\mathrm{OH})$, or not supplemented $(\mathrm{CON})$

\begin{tabular}{|c|c|c|c|c|c|}
\hline \multirow[b]{2}{*}{ Item } & \multicolumn{3}{|c|}{ Treatment } & \multirow[b]{2}{*}{ SEM } & \multirow[b]{2}{*}{$P$-value } \\
\hline & $\mathrm{CON}$ & $\mathrm{AH}$ & $\mathrm{OH}$ & & \\
\hline Muscular width, $\mu \mathrm{m}$ & 1,141 & 1,031 & 1,286 & 113.0 & 0.31 \\
\hline Papillae length, $\mu \mathrm{m}$ & $4,119^{\mathrm{a}}$ & $3,358^{\mathrm{ab}}$ & $2,784^{\mathrm{b}}$ & 317.5 & 0.04 \\
\hline Papillae width, $\mu \mathrm{m}$ & 289 & 327 & 260 & 49.3 & 0.63 \\
\hline Keratin layer, $\mu \mathrm{m}$ & 14.2 & 13.2 & 13.7 & 1.36 & 0.87 \\
\hline Papillae surface, $\mathrm{mm}^{2}$ & 1.4 & 1.3 & 0.8 & 0.31 & 0.45 \\
\hline
\end{tabular}

$\overline{\mathrm{a}, \mathrm{b}}$ Means within a row with different superscripts differ $(P<0.05)$. 
Table 9. Relative mRNA expression of selected genes (see Table 2) in the rumen epithelium and parotid gland, and abundance of Streptococcus bovis and Ruminococcus albus in ruminal and cecum contents at the slaughter of calves supplemented with alfalfa hay $(\mathrm{AH})$, oat hay $(\mathrm{OH})$, or not supplemented $(\mathrm{CON})$

\begin{tabular}{|c|c|c|c|c|c|}
\hline \multirow[b]{2}{*}{ Item } & \multicolumn{3}{|c|}{ Treatment } & \multirow[b]{2}{*}{ SEM } & \multirow[b]{2}{*}{$P$-value } \\
\hline & $\mathrm{CON}$ & $\mathrm{AH}$ & $\mathrm{OH}$ & & \\
\hline \multicolumn{6}{|l|}{ Rumen } \\
\hline$M C T-1$ & $0.08^{\mathrm{b}}$ & $0.36^{\mathrm{a}}$ & $0.36^{\mathrm{a}}$ & 0.097 & 0.10 \\
\hline$M C T-4$ & 0.01 & 0.01 & 0.02 & 0.011 & 0.85 \\
\hline SPC25 & 0.01 & 0.01 & 0.02 & 0.005 & 0.52 \\
\hline NHE-1 & $0.03^{\mathrm{ab}}$ & $0.04^{\mathrm{a}}$ & $0.02^{\mathrm{b}}$ & 0.006 & 0.08 \\
\hline NHE-3 & 0.20 & 0.55 & 0.25 & 0.130 & 0.15 \\
\hline$D R A$ & 0.05 & 0.17 & 0.14 & 0.059 & 0.33 \\
\hline \multicolumn{6}{|c|}{ Parotid gland } \\
\hline AQ5 & 20.2 & 22.6 & 23.6 & 6.49 & 0.93 \\
\hline TMEM16 & 0.69 & 0.44 & 0.88 & 3.623 & 0.28 \\
\hline \multicolumn{6}{|c|}{ Rumen population $^{1}$} \\
\hline S. bovis & 32.1 & 30.5 & 31.8 & 1.02 & 0.56 \\
\hline R. albus & 27.7 & 27.2 & 22.2 & 1.89 & 0.11 \\
\hline \multicolumn{6}{|c|}{ Cecum population $^{1}$} \\
\hline S. bovis & 33.0 & 31.9 & 30.9 & 0.96 & 0.26 \\
\hline R. albus & 33.4 & 35.3 & 32.0 & 1.67 & 0.41 \\
\hline
\end{tabular}

a,b Means within a row with different superscripts differ $(P<0.05)$ or tend to differ $(P<0.10)$.

${ }^{1}$ Cycle threshold values (smaller numerical values indicate greater abundance).

in forage than in non-forage-supplemented calves (Khan et al., 2011). Several authors (Jahn et al., 1970, 1976; Hill et al., 2008) have reported a decrease in EBW as the level of fiber in the diet increases. Those authors attributed the difference between live BW and EBW to the accumulation of digesta in the gastrointestinal tract (gut fill). Differences among experiments, and between $\mathrm{OH}$ and $\mathrm{AH}$ treatments in the present study, can be explained by the amount and physical form of forage included in the diet. In the present study, animals were offered chopped forage ad libitum, and forage intake was 14 and $4 \%$ of total solid feed intake for $\mathrm{AH}$ and $\mathrm{OH}$ calves, respectively. Most of the studies comparing different percentages of forage inclusion in the diet of young calves used forage intakes above $10 \%$ (Coverdale et al., 2004; Suárez et al., 2007) or they lacked a treatment where calves were deprived of forage (Stobo et al., 1966; Jahn et al., 1970); therefore, it is usually concluded that differences in BW when forage is provided to young calves are a consequence of a gut fill effect. However, from the present study, it can be envisaged that forage inclusion at the rate of $4 \%$ (such as that achieved when providing $\mathrm{OH}$ ) improves rumen environment and tends to improve ADG over time, without incurring in increases in gut fill.

Finally, differences in abomasum weights among treatments may be attributed to the differences observed in ruminal fractional passage rate. The increase of rumen passage rate in $\mathrm{OH}$ calves should result in more undigested feed reaching the abomasum and might induce greater development of the abomasum tissue. On the other hand, differences in the weight of the small intestine were not observed in the current study, similar to Kosiorowska et al. (2011), who compared 2 concentrates with different fiber levels,.

The results reported in the present study suggest 2 possible mechanisms that could be involved in the changes observed in rumen fermentation parameters when forage is included in the diet of young calves. First, differences in rumen epithelia gene expression could explain the lower rumen VFA concentration in forage-fed calves. Animals fed forage tended to show increased expression of MCT1 in the ruminal wall. This transporter is located in the basolateral membrane of the rumen epithelium and it is involved in the transport of lactate, acetate, and protons from the rumen epithelium into the bloodstream (Müller et al., 2002; Gäbel and Aschenbach, 2006; Kirat et al., 2006; Graham et al., 2007). Therefore, it could be speculated that due to the enhanced proton export, intracellular $\mathrm{pH}$ probably increased, and it may have heightened absorption of short-chain fatty acids (SCFA) from ruminal lumen into epithelium both by simple diffusion of protonated SCFA and by $\mathrm{SCFA}^{-} / \mathrm{HCO}_{3}^{-}$exchange. Despite the observed differences in NHE1 protein expression between $\mathrm{AH}$ and $\mathrm{OH}$ animals, overall expression of this gene was low, and thus the role of this protein in the control of intracellular $\mathrm{pH}$ homeostasis might not be very relevant.

An additional mechanism that could be responsible for the increased rumen liquid $\mathrm{pH}$ and decreased VFA concentrations in $\mathrm{OH}$ compared with $\mathrm{CON}$ calves may be related to the increase in the fractional rate of passage in the rumen observed in calves fed $\mathrm{OH}$ compared 
with $\mathrm{CON}$ and $\mathrm{AH}$. If rumen passage rate increases, the diet will have less time to be fermented, and, consequently, less VFA will be produced, leading to an increase in ruminal $\mathrm{pH}$ as was observed for $\mathrm{OH}$ calves. Moreover, because of the increased ruminal fractional passage rate, more digesta could reach the cecum, which could explain the greater VFA concentration in the cecum of animals with access to a forage source compared with calves offered no forage.

Finally, calves with access to a forage source have been shown to increase rumination time (Hodgson, 1971; Phillips, 2004; Martin et al., 2006; Castells et al., 2012). Therefore, a potential increase of saliva production associated with a hypothetical increased rumination could also explain the improvement in rumen $\mathrm{pH}$ observed in calves that had access to forage. However, in the current study, neither the rumen buffering capacity determined at slaughter nor the expression of genes from the parotid gland related to saliva production supported this hypothesis.

\section{CONCLUSIONS}

The inclusion of chopped forage in the diet of young calves leads to a better rumen environment because rumen $\mathrm{pH}$ increases and the expression of MCT1 transporter tends to increase. This improvement in rumen environment, together with an increase of ruminal passage rate, could allow greater intake of solid feed, and consequently an improvement in calf performance not linked to an increase in gut fill when consumption of forage is about $4 \%$ of total solid feed intake, as occurs when calves are offered chopped oat hay.

\section{ACKNOWLEDGMENTS}

We thank the Instituto Nacional de Investigación y Tecnología Agraria y Alimentarias (Madrid, Spain) for the financial support to conduct this research (RTA2008-00031-00-00). We also thank Xavier Robles and Agustí Molins (IRTA) for their help with calf care, and Alicia Serrano, Francesc Fàbregas, and Sílvia Parés (IRTA) for their help in the laboratory.

\section{REFERENCES}

AOAC. 1990. Official Methods of Analysis. 15th ed. Association of Official Analytical Chemists, Arlington, VA.

Bach, A., A. Giménez, J. L. Juaristi, and J. Ahedo. 2007. Effects of physical form of a starter for dairy replacement calves on feed intake and performance. J. Dairy Sci. 90:3028-3033.

Castells, Ll., A. Bach, G. Araujo, C. Montoro, and M. Terré. 2012. Effect of different forage sources on performance and feeding behavior of Holstein calves. J. Dairy Sci. 95:286-293.

Cline, J. H., T. V. Hershberger, and O. G. Bentley. 1958. Utilization and/or synthesis of valeric acid during the digestion of glucose, starch and cellulose by rumen micro-organisms in vitro. J. Anim. Sci. 17:284-292.

Colburn, M. W., J. L. Evans, and C. H. Ramage. 1968. Ingestion control in growing ruminant animals by the components of cell-wall constituents. J. Dairy Sci. 51:1458-1464.

Coverdale, J. A., H. D. Tyler, J. D. Quigley III, and J. A. Brumm. 2004. Effect of various levels of forage and form of diet on rumen development and growth in calves. J. Dairy Sci. 87:2554-2562.

Dhanoa, M. S., R. C. Siddons, J. France, and D. L. Gale. 1985. A multicompartmental model to describe marker excretion patterns in ruminant faeces. Br. J. Nutr. 53:663-671.

Drackley, J. K. 2008. Calf nutrition from birth to breeding. Vet. Clin. North Am. Food Anim. Pract. 24:55-86.

Gäbel, G., and J. R. Aschenbach. 2006. Ruminal SCFA absorption: Channelling acids without harm. Page 173 in Ruminant Physiology: Digestion, Metabolism and Impact of Nutrition on Gene Expression, Immunology and Stress. K. Sejrsen, T. Hvelplund, and M. O. Nielsen, ed. Wageningen Academic Publishers, Wageningen, the Netherlands.

Graham, C., I. Gatherar, I. Haslam, M. Glanville, and N. L. Simmons. 2007. Expression and localization of monocarboxylate transporters and sodium/proton exchangers in bovine rumen epithelium. Am. J. Physiol. Regul. Integr. Comp. Physiol. 292:R997-R1007.

Hill, T. M., H. G. Bateman II, J. M. Aldrich, and R. L. Schlotterbeck. 2008. Effects of the amount of chopped hay or cottonseed hulls in a textured calf starter on young calf performance. J. Dairy Sci. 91:2684-2693.

Hodgson, J. 1971. The development of solid food intake in calves. 1. The effect of previous experience of solid food, and the physical form of diets, on the development of food intake after weaning. Anim. Prod. 13:15-24.

Huhtanen, P., and U. Kukkonen. 1995. Comparison of methods, markers, sampling sites and models for estimating digesta passage kinetics in cattle fed at two levels of intake. Anim. Feed Sci. Technol. 52:141-158.

Jahn, E., P. T. Chandler, and R. F. Kelly. 1976. Nutrient accumulation and prediction of body composition of 20-week-old calves fed varying percentages of protein and fiber. J. Anim. Sci. 42:736-744.

Jahn, E., P. T. Chandler, and C. E. Polan. 1970. Effect of fiber and ratio of starch to sugar on performance of ruminating calves. J. Dairy Sci. 53:466-474.

Kertz, A. F. 2007. Letter to the Editor: Pelleted calf starter with straw access can confound results: A comment on Bach et al. (2007). J. Dairy Sci. 90:4924.

Khan, M. A., D. M. Weary, D. M. Veira, and M. A. G. von Keyserlingk. 2012. Postweaning performance of heifers fed starter with and without hay during the milk-feeding period. J. Dairy Sci. 95:3970-3976.

Khan, M. A., D. M. Weary, and M. A. G. von Keyerslingk. 2011. Hay intake improves performance and rumen development of calves fed higher quantities of milk. J. Dairy Sci. 94:3547-3553.

Kirat, D., J. Masuoka, H. Hayashi, H. Iwano, H. Yokota, H. Taniyama, and S. Kato. 2006. Monocarboxylate transporter 1 (MCT1) plays a direct role in short-chain fatty acids absorption in caprine rumen. J. Physiol. 576:635-647.

Kosiorowska, A., L. Puggaard, M. S. Hedemann, J. Sehested, S. K. Jensen, N. B. Kristensen, P. Kuropka, K. Marycz, and M. Vestergaard. 2011. Gastrointestinal development of dairy calves fed lowor high-starch concentrate at two milk allowances. 2011. Animal 5:211-219.

Laarman, A. H., A. L. Ruiz-Sanchez, T. Sugino, L. L. Guan, and M. Oba. 2012. Effects of feeding a calf starter on molecular adaptations in the ruminal epithelium and liver of Holstein dairy calves. J. Dairy Sci. 95:2585-2594.

Martin, C., L. Brossard, and M. Doreau. 2006. Mechanisms of appearance of ruminal acidosis and consequences on physiopathology and performances. Prod. Anim. 19:93-107.

McLeod, M. N., P. M. Kennedy, and D. J. Minson. 1990. Resistance of leaf and stem fractions of tropical forage to chewing and passage in cattle. Br. J. Nutr. 63:105-119. 
Moseley, G., and J. R. Jones. 1979. Some factors associated with the difference in nutritive value of artificially dried red clover and perennial ryegrass for sheep. Br. J. Nutr. 42:139-147.

Moseley, G., and J. R. Jones. 1984. The physical digestion of perennial ryegrass (Lolium perenne) and white clover (Trifolium repens) in the foregut of sheep. Br. J. Nutr. 52:381-390.

Müller, F., K. Huber, H. Pfannkuche, J. R. Aschenbach, G. Breves, and B. Gäbel. 2002. Transport of ketone bodies and lactate in the sheep ruminal epithelium by monocarboxylate transporter 1. Am. J. Physiol. Gastrointest. Liver Physiol. 283:G1139-G1146.

Petri, R. M., R. J. Forster, W. Yang, J. J. McKinnon, and T. A. McAllister. 2012. Characterization of rumen bacterial diversity and fermentation parameters in concentrate fed cattle with and without forage. J. Appl. Microbiol. 112:1152-1162.

Phillips, C. J. C. 2004. The effects of forage provision and group size on the behavior of calves. J. Dairy Sci. 87:1380-1388.

Stobo, I. J. F., J. H. B. Roy, and H. J. Gaston. 1966. Rumen development in the calf. 1 . The effect of diets containing different proportions of concentrates to hay on rumen development. Br. J. Nutr. 20:171-188.

Suárez, B. J., C. G. Van Reenen, N. Stockhofe, J. Dijkstra, and W. J. J. Gerrits. 2007. Effect of roughage source and roughage to concentrate ratio on animal performance and rumen development in veal calves. J. Dairy Sci. 90:2390-2403.
Thomas, D. B., and C. E. Hinks. 1982. The effect of changing the physical form of roughage on the performance of the early-weaned calf. Anim. Prod. 35:375-384.

Tucker, W. B., J. F. Hogue, M. Aslam, M. Lema, M. Martin, F. N. Owens, I. S. Shin, P. Le Ruyet, and G. D. Adams. 1992. A buffer value index to evaluate effects of buffers on ruminal milieu in cows fed high or low concentrate, silage, or hay diets. J. Dairy Sci. $75: 811-819$.

Van Soest, P. J., J. B. Robertson, and B. A. Lewis. 1991. Methods for dietary fiber, neutral detergent fiber, and nonstarch polysaccharides in relation to animal nutrition. J. Dairy Sci. 74:3583-3597.

Voelker-Linton, J. A., and M. S. Allen. 2007. Nutrient demand affects ruminal digestion responses to a change in dietary forage concentration. J. Dairy Sci. 90:4770-4779.

Wang, R. F., W. W. Cao, and C. E. Cerniglia. 1997. PCR detection of Ruminococcus spp. in human and animal faecal samples. Mol. Cell. Probes 11:259-265.

Williams, C. H., D. J. David, and O. Iismaa. 1962. The determination of chromic oxide in faeces samples by atomic absorption spectrophotometry. J. Agric. Sci. 59:381-385.

Yu, Z., and M. Morrison. 2004. Improved extraction of PCR-quality community DNA from digesta and fecal samples. Biotechniques 36:808-812. 